\title{
sciendo ON DECK OIL SPILL CLEAN-UP MATERIALS - SOLUTION FOR ENGINE ROOMS
}

DOI 10.2478/ntpe-2018-0001

\author{
Dr. Eng. Agnieszka Ubowska \\ Eng. Katarzyna Jowtuch \\ West Pomeranian University \\ of Technology Szczecin, Poland
}

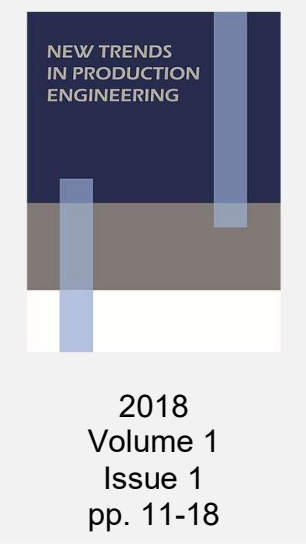

\begin{abstract}
The presence of flammable substances nearby hot surfaces in the engine rooms pose a fire hazard. Therefore the quick and effective removal of oil spills from these areas is of utmost importance. The simplest way is to use sorbent materials having the capacity to absorb oil substances. Oil sorbents comprise of a wide range of organic, inorganic and synthetic products. The choice of form and type of sorbent material depends on the intended application: type of spill, its size and location. The article describes the results of studies aimed to compare the absorbency of selected natural and synthetic sorbents in the context of their application in case of an oil spill in the engine room. Although the natural sorbents should not be used in water, because they absorb it and can in addition contaminate the seabed, they can be used to remove oil spills on the ship. After used they can be disposed on the ship by burning.
\end{abstract}

Keywords: oil spill, engine room, sorbent

\section{INTRODUCTION}

Maritime transport is associated with the production of various kinds of pollution, including those related to unforeseen circumstances and impossible to stop failures or disasters in extreme cases. Most types of pollution generated in the maritime are oil impurities - petroleum and petroleum-derived substances, such as lubricating oil, hydraulic oil or heating oil (Fabisiak, 2008; Treichel and Wiewióra, 2008). In order to prevent contamination of the marine environment of these substances a number of regulations, methods and technical means were developed. They are designed to regulate the amount and types of pollution entering the marine waters, preventive measures and actions aimed at eliminating the damage caused by leakage of oil. To comply with the International Maritime Regulations and Oil Pollution Act of 1990 all vessels are required to carry on board sufficient materials to mop up oil spills:

- tankers 400 feet or greater in length which are carrying oil in bulk must be equipped to deal with 12 barrels worth of deck spill;

- tankers under 400 feet shall have equipment to handle 7 barrels worth of deck spill;

- in-land oil barges must be able to deal with at least 1 barrel worth of desk spill.

Oil spill kit is a response to meet these requirements, in conjunction with ship's response plan. The sorbent kit consists of various types of sorbents such as booms, pillows and pads for use at any oil spill location on board a vessel (101st United States Congress, 1990; International Maritime Organization, 2014).

These materials have different sizes and have various absorption abilities. In addition, the kit also includes loose sorbents, e.g. in the form of granules, various auxiliary elements, i.e. shovels or buckets, materials for the storage of used sorbents and personal protective equipment (1time suits, gloves and safety shoes) (Fig.1).

All ships with 400 GT and above must carry an oil prevention plan SOPEP (Ship oil pollution emergency plan). For oil tankers the Gross Tonnage requirement is reduced to $150 \mathrm{GT}$. The person responsible for SOPEP on vessel is the master who, together with the chief officer, supervises the implementation of SOPEP on board. SOPEP describes the plan for the master, officer and the crew to follow in the case of various oil spill scenario. Shipboard oil pollution 
emergency plan contain among others a list of clean up of an on deck oil spill (International Maritime Organization, 2011).

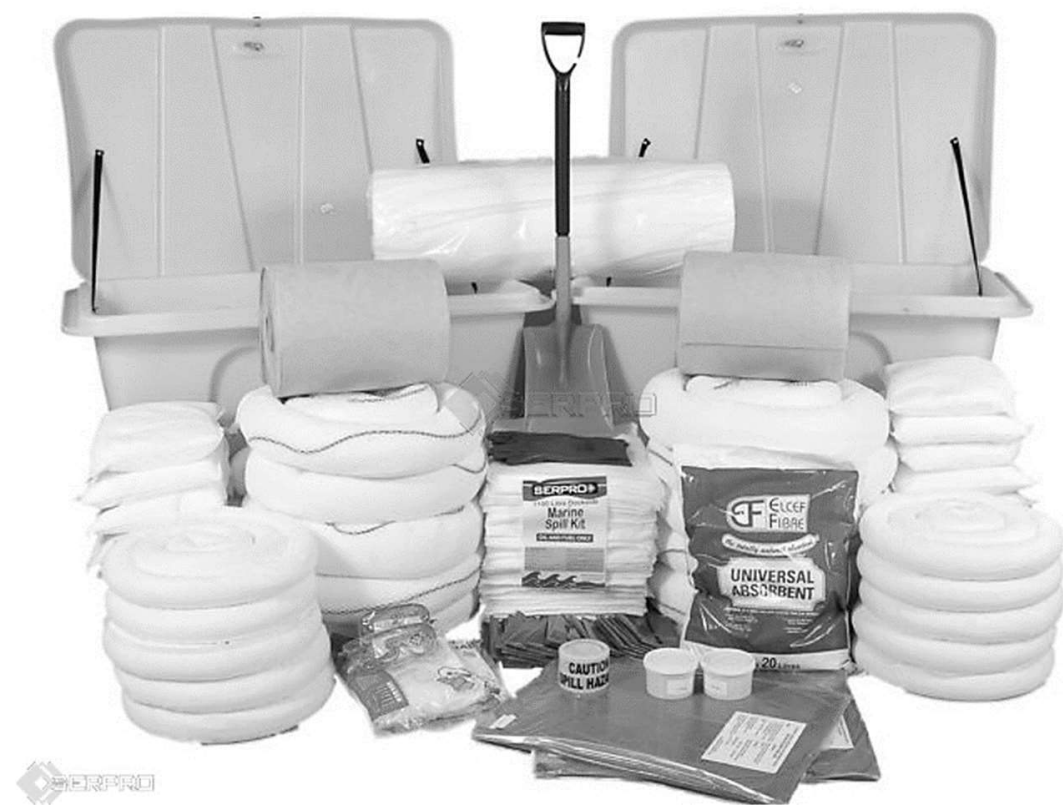

Source: Serpro, 2018.

Fig. 1. 1100 liter dockside Marine Oil Spill Kit.

\section{Oil pollutants in engine rooms}

The source of most fuel oils for marine use is crude oil. Fuel oils vary in such characteristics as specific gravity, viscosity, ignition quality, flash point, or calorific value. Differences in properties determine their performance (Taylor, 1996). Smaller ships typically are propelled by diesel oil, while larger and slower cargo vessels consume heavier fuel oils. Nuclear propulsion is used in only a few nuclear-powered icebreakers (Vergara et al., 2012).

In the case of engine room most dangerous event is damage to the main engine, which can cause the release of the largest amount of oil. In a smaller extent, the risk of oil leakage is caused by auxiliary motors and other devices that use the operating cycle oil derivatives. Main engine and auxiliary engines are part of the propulsion system of the vessel (Girtler et al., 2003). Examples of reasons for entering oily substances on the unit or outside the vessel are many. One of them may be engine failure resulting from improper, a provisional repair of oil leakage, which ultimately leads to the formation of large leaks. The effect of the leak in the engine can be a flow of cooling oil and lubricating oil, which can lead to seizure of the main engine and the formation of small oil spill (Bądkowski, 1985).

Requirements for machinery spaces of in MARPOL $73 / 78$ relate to:

- equipment machinery in tank (tanks) to receive the oil residues (sludge) which cannot be dealt with otherwise (resulting from the purification of fuel and lubricating oils and oil leakages in the machinery spaces);

- dimensions of flanges for discharge connections;

- oil filtering equipment;

- control of discharge of oil;

- segregation of oil and water ballast and carriage of oil in forepeak tanks;

- Oil Record Book (International Maritime Organization, 2011).

\section{Marine sorbents}

One of the most important issues for water ecosystem is it's contamination with oil, caused by marine transport. Various technologies like mechanical, chemical and biological treatment, insitu burning, membrane filtration or sorption have been developed to treat oil-contaminated water. The last method is also used to remove oil spills on ships. 
According to ASTM F716 - 09 sorbent is an insoluble material or mixture of materials used to recover liquids through the mechanisms of absorption or adsorption, or both (ASTM International, 2009). Marine sorbents materials are used to removing thin oil layer from the water or small amount of oil from beaches. They are also used on the deck during the leak of fluids. Oil sorbent materials can act either by adsorption or, less commonly, by absorption. The absorbtive capacity depend on the surface area to which the oil can adhere. The oil also entrapped in voids such as pores and capillaries. The oil sorbents work best on heavy, high viscous oils. The time needed to uptake oil should be fast - less than one minute. Sorbent for oil cleanup besides high sorption capacity and uptake rate should be characterized by high hydrophobicity and oleophilicity, low-cost and ready availability (Doerffer, 1992).

Taking into account the origin there are three different types of sorbents:

- natural organic;

- mineral based;

- synthetic organic.

Natural sorbents like ground corn cob, peanut hulls, redwood fiber, sawdust, wheat straw or wood cellulose fiber are nontoxic and biodegradable. They are hydrophilic which mains that adsorb oil as well as water. Natural sorbents absorb three to six times their weight in oil (Abdelwahab et al., 2017; Yang et al., 2017).

Mineral-based sorbents like perlite, vermiculite or volcanic ash are nonbiodegradable, dangerous to humans because of the potential respiratory irritations due to inhalation of their dust. Because of their very low specific weight they are also difficult to distribute by the windy weather. Mineral-based sorbents absorb four to eight times their weight in oil (Teas et al., 2001). Synthetic organic sorbents like polyurethane foams, urea formaldehyde foam, polystyrene powder, polyester shavings because of their form are easy to spread. They also show much greater efficiency independent of oil viscosity but their price is also higher (Doerffer, 1992; International Tanker Owners Pollution Federation, 2012).

Taking into account the form distinguishes sorbents:

- type I absorbent (roll, film, sheet, pad, blanket, web): a material with length and width much greater than thickness and which has both linear form and strength sufficient to be handled either saturated or unsaturated,

- type II absorbent (loose): an unconsolidated, particulate material without sufficient form and strength to be handled except with scoops and similar equipment,

- type III adsorbent (enclosed): pillows or adsorbent booms.

The cost of sorbent dependent upon the material used. Organic and inorganic materials are less expensive than synthetic products. However, their low relative efficiency can require the additional quantities to deal with the oil. The additional costs of disposal of higher volumes of material should also be considered. As with storage, transportation of large volumes of sorbents can cause logistical problems, whereas organic and inorganic sorbents may be less efficient, they are often widely available (International Tanker Owners Pollution Federation, 2012).

The marine oil spit kit consists mainly synthetic sorbents. Thanks to the fact that they are characterized by high efficiency, enable the completion of a set of optimum size that meets regulatory requirements. Their disadvantage is the high price. Therefore, in the case of small oil spills on the ship natural sorbents are used, which after use are disposed in the ship burner.

The aim of the study was to determine the absorbency of selected bulk sorbents for potential use in the engine room.

\section{METHODOLOGY OF RESEARCH Method}

Studies have been carried out by Westinghouse (Fig. 2).

This is a method for studying the absorption capacity of sorbents used in paved areas, and thus it can be used to test the absorbency of sorbents in the context of their application on the ship, and in particular in engine room. Method involves: 
- immersing $10 \mathrm{~g}$ of the sorbent contained in a cone of stainless steel mesh in the oil for 10 minutes;

- standing cone with sorbent into the beaker to drain the excess substance for 5 minutes;

- weighting the sample and calculated the sorption capacity, from the equation 1.

$$
C=\frac{m_{2}-m_{1}}{m_{1}}
$$

where:

C - sorption capacity, grams oil/grams sorbents;

$\mathrm{m}_{1}$ - the mass of dry sorbent before oil sorption test, $\mathrm{g}$;

$\mathrm{m}_{2}$ - the mass of wet sorbent after sorption for $10 \mathrm{~min}, \mathrm{~g}$.

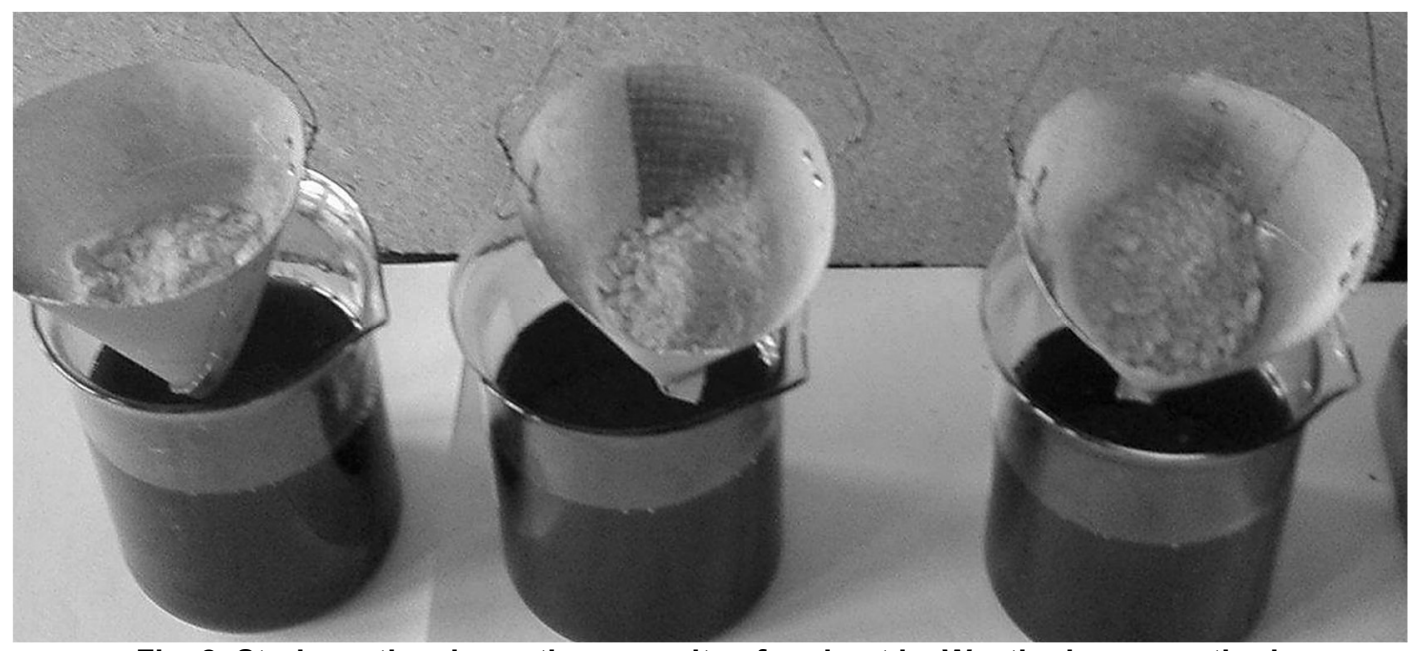

Fig. 2. Study on the absorption capacity of sorbent by Westinghouse method.

\section{Materials}

Eight materials with sorption properties were selected for the study (Fig. 3).

Sawdust (Fig. 3a) is a sorbent of natural origin derived from mechanical wood processing. They are used to absorb a variety of substances except some acids. They are characterized by varying particle sizes.

Sand (Fig. 3b) is a naturally occurring granular material composed of finely divided rock and mineral particles, mostly silica (silicon dioxide) usually in the form of quartz. It is a natural sorbent, having a low cost of purchase and unlimited access. Sand is relatively often used by emergency services, either for the uptake of petroleum products or for chemicals or toxic substances. The sand used in the test had a grain size of $>35 \mathrm{~mm}$.

Active carbon (Fig. 3c) consists of fine crystalline graphite and elemental carbon. In the form of the transformed, it is used for the absorption of certain substances. As an adsorbent it is used to absorb impurities. The sorbent of International Enzymes Limited with a diameter of $0.4 \div 0.5$ $\mathrm{mm}$ was used for the studies.

Talc (Fig. 3d) is obtained from the mechanical processing of steatite. It is used as an additive for paints and varnishes but also as a sorbent. The technical type of talc Alfa, manufactured in Slovakia, were used.

Compakt (Fig. $3 \mathrm{e}$ ) is a universal sorbent from Sintac Polska. It is a natural mineral sorbent. It collects both spills of petroleum products and other chemicals from hardened surfaces. It is indispensable in chemical and ecological rescue and in the removal of spills in industrial halls, chemical warehouses, fuel bases, fuel stations, garages, transport. It works in both closed and open spaces.

Granulation: 0.3-0.7 mm (Sintac, 2018).

OEL-KLEEN Universalbinder (Fig. 3f) based on calcium silicate. It's hydrophobic universal binding agent. Sorbent is non-flammable which can be used both indoor and outdoor.

Main application: road surfaces, cleaning and protection of industrial floors, cleaning dangerous oil spills. 
Usefulness: oils, waste oils, greases, solvents, hydrocarbons.

Granulation: 0.125 $\div 1 \mathrm{~mm}$ (Opti, 2018).

OEL-KLEEN Kerasorb SuperPlus (Fig. $3 \mathrm{~g}$ ) is a diatomite based sorbent. It is a natural granule, without additives, obtained by mechanical and thermal treatment. Universal sorbent used to absorb water, oils and chemicals.

Main application: road and chemical rescue, industry.

Usefulness: oil and chemicals.

Granulation: 0.3-0.7 mm (Opti, 2018).

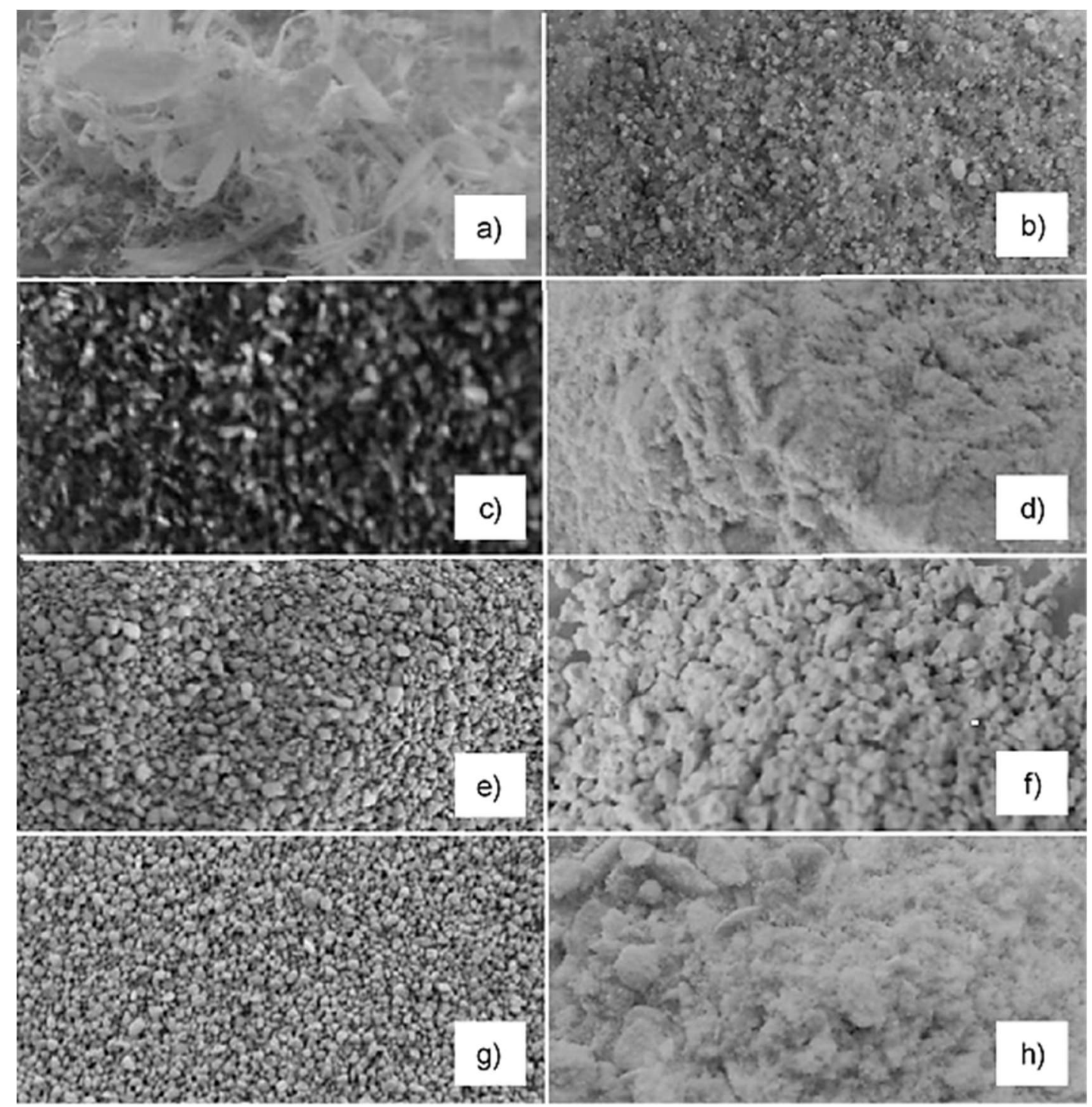

Fig. 3. Tested sorbents materials:

a) sawdust, b) sand, c) active carbon, d) talc, e) sorbent Compakt,

f) OEL-KLEEN Universalbinder, g) OEL-KLEEN Kerasorb SuperPlus, h) OEL-KLEEN 2000

OEL-KLEEN 2000 (Fig. 3h) is an oil bonding agent based on polyurethane foam, hydrophobic and floatable. The oil absorption of OEL KLEEN 2000 is hardly reduced by water.

Main application: industry, roads, waterways, other communication areas.

Usefulness: oil and greasy dirt.

Granulation: 0.125-4 mm (Opti, 2018).

Marinol RG 1230 is the Trunk Piston Engine Oil Motor (TPEO) oil. Is formulated on the base of deeply refined, solvent dewaxed and hydrorefined oil distillates received from crude oil. It contains a package of washing and dispersing additives as well as antioxidising, anticorrosion, antirust and anti-wear attributes (Lotos, 2017). Characteristics of Marinol RG 1230 presents Table 1. 
Table 1

Characteristics of Marinol RG 1230

Source: Lotos, 2017.

\begin{tabular}{|l|l|}
\hline \multicolumn{1}{|c|}{ Parameter } & \multicolumn{1}{c|}{ Value } \\
\hline Kinematic viscosity at $100^{\circ} \mathrm{C}$ & $11.8 \mathrm{~mm}^{2} / \mathrm{s}$ \\
\hline Pour point & $-24^{\circ} \mathrm{C}$ \\
\hline Flash point & $270^{\circ} \mathrm{C}$ \\
\hline Base number & $12.4 \mathrm{mgKOH} / \mathrm{g}$ \\
\hline Viscosity index & 100 \\
\hline
\end{tabular}

\section{RESULTS AND DISCUSSION}

The choice of sorbent for use to remove oil spills on ships was based on comparing the sorption capacity. The sorption capacity is affected by the grain size, but also the specific weight of the sorbent. The tested sorbents differed in particle size, physical and chemical properties, so the absorbency of the tested sorbents was varied. The major group of tested sorbents was based on mineral materials, widely available on the market. Mineral sorbents were characterized by a sorption capacity of 0.2 to 1.3 grams of oil /gram of sorbent (Table 2). The smallest oil absorption was characterized by sand, which despite its low efficiency is often used to remove oil spills at gas stations. The best sorption capacity has been noted for Kerasorb SuperPlus - more than six times higher than for sand. The most effective sorbents were sawdust and synthetic sorbent OEL-KLEEN 2000. The oil sorption capacity measured for both of them was 2.8 (fourteen times as much as the sand).

Table 2

Oil sorption capacity (grams oil/grams sorbent)

\begin{tabular}{|l|l|c|}
\hline \multicolumn{2}{|c|}{ Sorbent } & Sorption capacity \\
\hline Natural sorbent & sawdust & 2.8 \\
\hline \multirow{5}{*}{ Mineral sorbent } & sand & 0.2 \\
\cline { 2 - 3 } & active carbon & 1.0 \\
\cline { 2 - 3 } & talc & 0.5 \\
\cline { 2 - 3 } & Sorbent Compakt & 1.1 \\
\cline { 2 - 3 } & OEL-KLEEN Universalbinder & 0.8 \\
\cline { 2 - 3 } & OEL-KLEEN Kerasorb SuperPlus & 1.3 \\
\hline Synthetic sorbent & OEL-KLEEN 2000 & 2.8 \\
\hline
\end{tabular}

Figure 4 shows the oil sorption capacity expressed in \%.

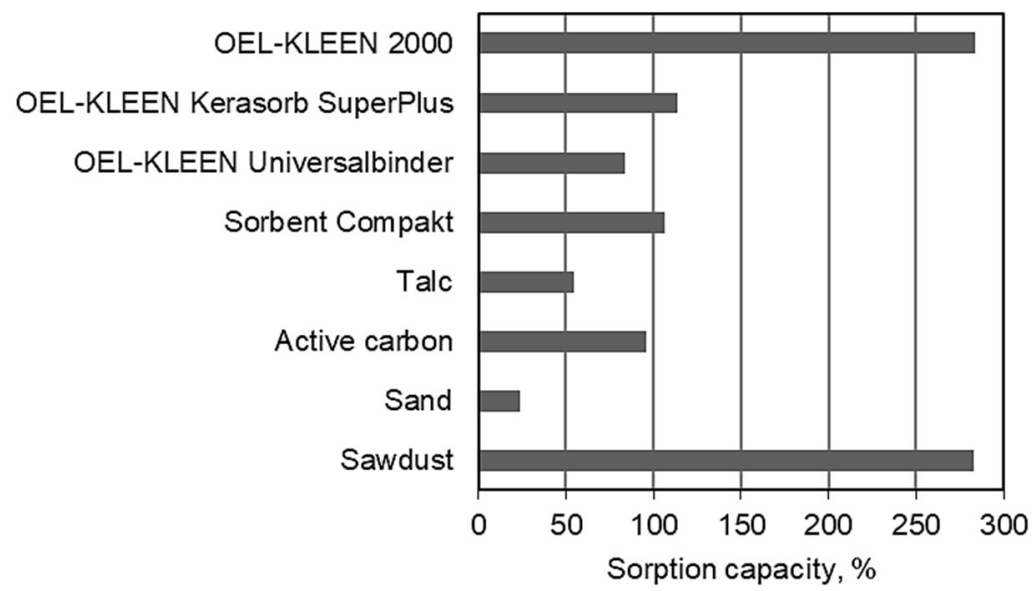

Fig. 4. Oil sorption capacity (\%).

Apart from the absorption there are also features such as weight or price of sorbent material as well as safety aspect (Table 3 ).

Both sawdust and sorbent OEL-KLEEN 2000 are flammable materials. Their dust may form explosive mixtures with air. The bulk density and ignition temperatures values are similar for 
both materials so it have to be stored in the same conditions. The main factor by choosing one from those two sorbent materials is economic, which is in favor of using sawdust.

Table 3

Characteristic of most efficient sorbent materials

\begin{tabular}{|c|c|c|c|c|}
\hline 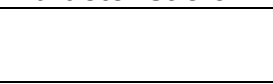 & $\begin{array}{c}\text { Bulk density, } \\
\mathrm{kg} / \mathrm{m}^{3}\end{array}$ & Flashpoint, ${ }^{\circ} \mathrm{C}$ & $\begin{array}{c}\text { Self-ignition } \\
\text { temperature, }{ }^{\circ} \mathrm{C}\end{array}$ & $\begin{array}{c}\text { Price, } \\
\text { zloty/kg }\end{array}$ \\
\hline OEL-KLEEN 2000 & 250 & ca. 300 & ca. 400 & ca. 3.7 \\
\hline Sawdust & $160-280^{*}$ & $210-350^{*}$ & $310-450^{*}$ & ca. $0.4^{x x}$ \\
\hline
\end{tabular}

depends on the trees species

${ }^{x x}$ pine sawdust

\section{CONCLUSION}

The negative effects of oil pollution in the marine environment, caused mainly by sea transport, have led to the emergence of a number of legal determinants of how to deal with spills. Due to the problem, the search for ways to remove oil spills was started, both on the open sea and on board the vessel. Sorption materials are used to remove spills from vessel. The absorption of selected sorbents was determined by the experimental Westinghouse method, typical used to studying the sorption capacity of sorbents used in paved areas. Organic, mineral and synthetic sorbents were used. The sorption capacity of sorbents was determined using engine oil Marinol RG 1230 from Lotos Oil. The highest absorbency of all tested sorbents has been noted for synthetic sorbent OEL-KLEEN 2000 and sawdust (natural organic sorbent). There is no need to use specialized sorption materials to remove oil spills during operating leaks in engine room.

\section{REFERENCES}

Fabisiak, J. (2008). Zagrożenia ekologiczne Bałtyku związane z zanieczyszczeniami chemicznymi - węglowodory. Zeszyty Naukowe Akademii Marynarki Wojennej, 174 (3), pp. 7-28.

Treichel, P. and Wiewióra, A. (2008). Problemy oczyszczania mieszanin oleistych, powstających podczas eksploatacji statku. Problemy Eksploatacji, 2, pp. 231-238.

101st United States Congress (1990). Oil Pollution Act of 1990 - Public Law 101-380. International Maritime Organization, (2014). International Maritime Dangerous Goods Code: incorporating amendment 37-14.

Serpro (2018). Available at: https://www.serpro.co.uk [Accessed 7 Mar. 2018].

International Maritime Organization (2011). MARPOL 73/78 Annex I, Regulations for the Prevention of Pollution by Oil.

Taylor, D.A. (1996). Introduction to Marine Engineering (Second Edition), United Kingdom: Elsevier Science \& Technology.

Vergara, Y.J., McKesson, Ch. and Walczak M. (2012). Sustainable energy for the marine sector. Energy Policy, 49, pp. 333-345.

Girtler, J. Kuszmider, S. and Plewiński, L. (2003). Wybrane zagadnienia eksploatacji statków morskich w aspekcie bezpieczeństwa żeglugi. Szczecin: Wyższa Szkoła Morska w Szczecinie.

Bądkowski, A. (1985) Rozlewy olejowe na morzu: Przyczyny Zapobieganie Wykrywanie Zwalczanie Największe katastrofy. Gdańsk: Wydawnictwo Morskie.

ASTM International (2009). ASTM F716-09: Standard Test Methods for Sorbent Performance of Absorbents, West Conshohocken: PA.

Doerffer, J.W. (1992). Oil spill response in the marine environment. Oxford, New York, Seoul, Tokyo: Pergamon Press.

Abdelwahab, O., Nasr, S. M. and Thabet, W. M. (2017). Palm fibers and modified palm fibers adsorbents for different oils. Alexandria Engineering Journal, 56(4), pp. 749-755.

Yang, L. Wang, Z. Yang, L. Li, X. Zhang, Y. and Lu, Ch. (2017). Coco peat powder as a source of magnetic sorbent for selective oil-water separation. Industrial Crops and Products, 101, pp. 1-10.

Teas, C. Kalligeros, S. Zanikos, F. Stournas, S. Lois, E. and Anastopoulos, G. (2001). Investigation of the effectiveness of absorbent materials in oil spills clean up. Desalination, $140(3)$, pp. 259-264.

International Tanker Owners Pollution Federation (2012). Use of sorbent materials in oil spill response. Information paper 8, Canterbury: Impact PR \& Design Limited.

Sintac (2018). Available at: http://sintac.eu/eng/02.html [Accessed 7 Mar. 2018].

Opti (2018). Available at: http://sorbenty-oelkleen.pl/produkty.html [Accessed 7 Mar. 2018]. 
Lotos (2017). Available at: http://www.lotosoil.pl/en/home-page/produkty/olejezeglugowe,2,388,show, 12212 [Accessed 4 Nov. 2017].

Date of submission of the article to the Editor: 02/2018

Date of acceptance of the article by the Editor: 06/2018 